\title{
The Kamchatkan Volcanic Eruption Response Team (KVERT)
}

ussia's Kamchatka Peninsula
is home to 29 active volcanoes,
including 7 snow-capped strato-
cones more than $10,000 \mathrm{ft}(3,000 \mathrm{~m})$
high. Several eruptions each year
in Kamchatka produce ash clouds
that threaten the safety of air travel
across the North Pacific, including
travel between the United States and
Russia and Japan. The Kamchatkan
Volcanic Eruption Response Team
(KVERT), created in 1993 through a
cooperative effort of Russian and
U.S. scientists, monitors the volca-
noes of Kamchatka to provide warn-
ings and rapid reporting of eruptions.

Russia's Kamchatka Peninsula, across the Bering Sea from Alaska, has 29 active volcanoes. Although only a few of these pose a direct threat to the peninsula's sparse population, an eruption from any of them can be a serious threat to aviation throughout the entire North Pacific region. In a typical year, 3 or 4 explosive eruptions in Kamchatka send tiny jagged particles of rock and glass (volcanic ash) high into the atmosphere and across heavily traveled international air routes between Asia and North America.

Volcanic ash is extremely hazardous to flying jet aircraft. Encounters with ash clouds can cause jet engines to fail suddenly, because ash can erode compressor blades and melt and solidify onto moving parts. Ash clouds can drift with prevailing winds for many days and thousands of miles and still be a hazard to aircraft. Worldwide, more than 100 jet aircraft in the past 20 years have inadvertently entered ash clouds, causing hundreds of millions of dollars in damage. Although no fatal incidents have yet occurred, many encounters have been close calls.

The threat of volcanic ash to aircraft can be reduced through warnings of eruptions, timely detection and tracking of ash clouds, and effective communication of the hazard to authorities and the aviation community. In 1993, recognizing the need for rapid detec-

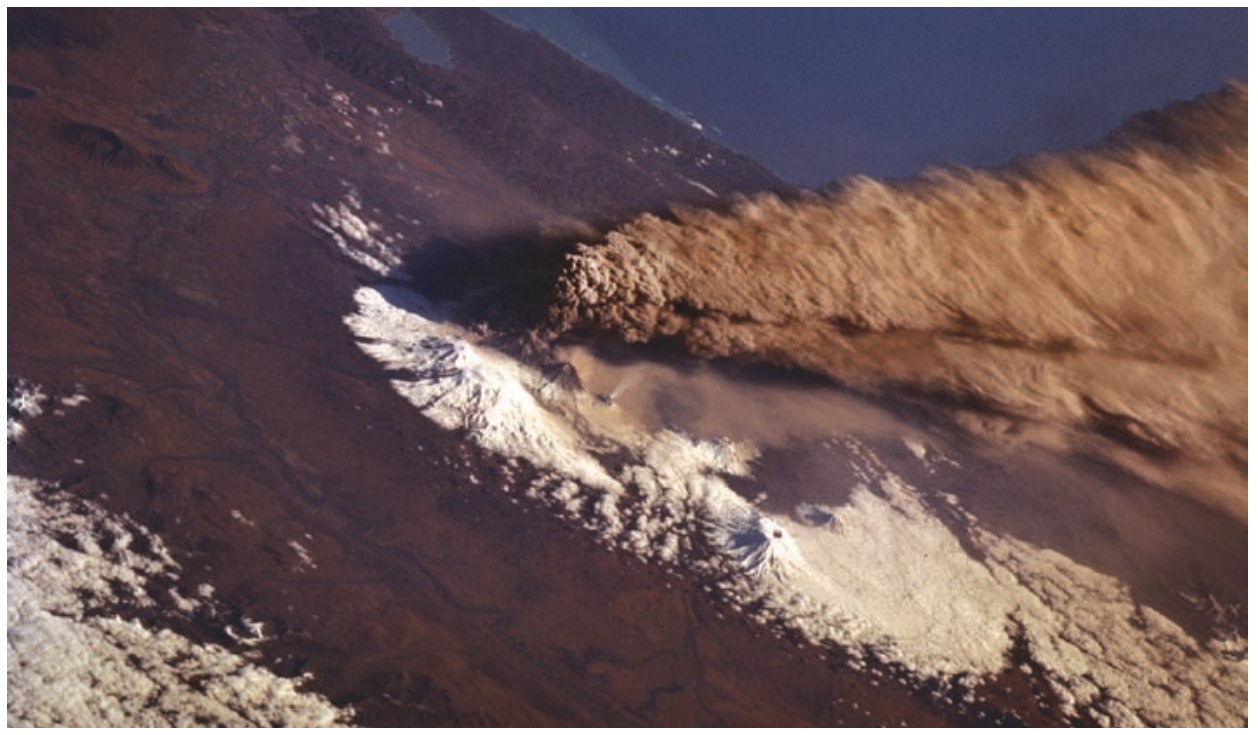

In October 1994, Klyuchevskoy Volcano in northern Kamchatka erupted explosively, sending a column of volcanic ash more than 9 miles $(15 \mathrm{~km})$ into the air. This photograph taken from a space shuttle shows the ash cloud as high winds blow it southeastward over the North Pacific Ocean. The cloud crossed busy air routes in both Russian and U.S. airspace. Warnings from the Kamchatkan Volcanic Eruption Response Team (KVERT) were crucial to enabling the safe rerouting of North Pacific air traffic until the threat subsided. (Photograph courtesy of NASA.) tion of volcanic eruptions occurring in the northwest Pacific, scientists with the Russian Academy of Sciences Institute of Volcanic Geology and Geochemistry (IVGG) and the Kamchatkan Experimental and Methodical Seismological Department (KEMSD) created the Kamchatkan Volcanic Eruption Response Team (KVERT). This was done in close col- laboration with the Alaska Volcano Observatory (AVO), a cooperative effort of the U.S. Geological Survey (USGS), University of Alaska Fairbanks Geophysical Institute, and Alaska Division of Geological and Geophysical Surveys. Funding for KVERT and its staff of about a dozen full- and part-time scientists has been provided by several organizations,

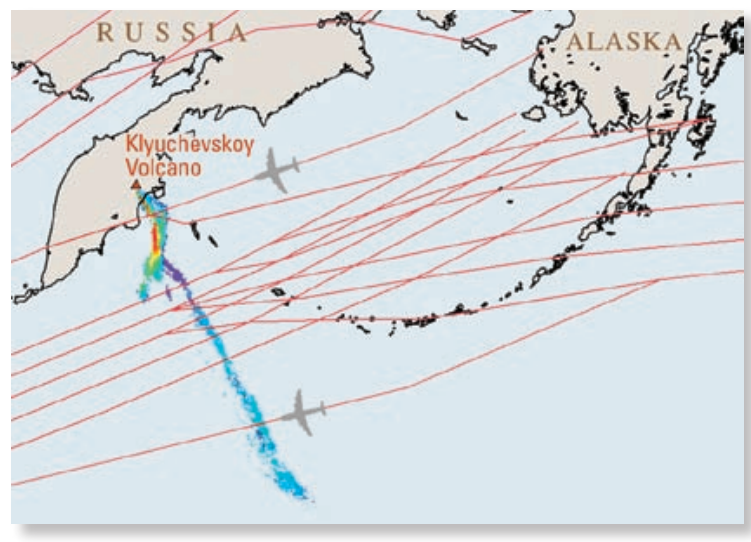

An AVHRR satellite image of the ash cloud from the October 1, 1994, eruption of Klyuchevskoy Volcano is shown here superimposed on a simplified map of North Pacific air routes. Each day, aircraft flying along these routes, some of the busiest in the world, carry more than 20,000 passengers and cargo worth millions of dollars to and from Asia, North America, and Europe. (Satellite image processed by David Schneider, Alaska Volcano Observatory.) Satellite images are a powerful tool used to detect volcanic eruptions and track the movements of ash clouds. In cooperation with the Alaska Volcano Observatory, KVERT examines data from Japanese and U.S. meteorological satellites to detect and monitor the eruptive activity of Kamchatkan and some Kurile Island volcanoes. Several times a day, images from GMS (Geostationary Meteorological Satellite), GOES (Geostationary Operational Environmental Satellites), and polar-orbiting satellites carrying AVHRR (Advanced Very High Resolution Radiometer) are scrutinized for evidence of ash or thermal anomalies that might indicate volcanic activity. 
The Kamchatka Peninsula has 29 active volcanoes, several of them near Petropavlovsk-Kamchatsky, a city of 200,000 people, where KVERT is based. The most effective method of detecting unrest at volcanoes is seismic (earthquake) monitoring. As of 2002, 27 remote seismic monitoring stations (see inset) are operating at 9 of the most active volcanoes in Kamchatka and at Alaid Volcano on Atlasova Island in the northern Kurile Islands. Data are transmitted from the stations to three recording centers in Petropavlovsk-Kamchatsky, Klyuchi, and Kozyrevsk. Internet connectivity among these centers allows KVERT scientists to rapidly analyze data and issue notifications of volcanic unrest at the monitored volcanoes. Direct visual observations are also important in confirming volcanic eruptions and making hazard assessments. For Kam chatkan volcanoes not visible from KVERT headquarters, visual reports are received from technical observers in Klyuchi and Kozyrevsk by telephone, radio, and e-mail. In 2000, a video-camera system was installed in Klyuchi, which, weather permitting, makes real-time images of Klyuchevskoy Volcano available on the Internet (http://data.emsd.iks.ru/video/ video.htm). A similar system was installed in May 2002 for Sheveluch Volcano, and additonal systems are planned for other Kamchatkan volcanoes. (Photo courtesy of Yury Demyanchuk, Kamchatkan Experimental and Methodical Seismological Department.)

including the International Air Transport Association, U.S. Agency for International Development, USGS, and the Russian State Unitary Enterprise Kamchatkaeronavigatziya.

The most effective method of detecting unrest at volcanoes is seismic (earthquake) monitoring. As of 2002, 27 remote seismic monitoring stations are operating at 9 of the most active volcanoes in Kamchatka and at Alaid Volcano, on Paramushir Island in the northern Kurile Islands. Direct visual observations are also important in confirming volcanic eruptions and making hazard assessments. They allow scientists to calibrate seismic data in order to remotely interpret volcanic activity. KVERT scientists have developed methods of estimating eruption plume height from the intensity of seismicity. This is an important tool in Kamchatka, where many volcanoes are remote and frequently obscured by clouds. Analysis of satellite imagery is another powerful technique used to detect volcanic eruptions and track the movements of ash clouds.

KVERT provides frequent status reports and notices of volcanic activity in Kamchatka, by telephone and over the Internet, to local authorities and through them and AVO to the international community. The level of hazard at Kamchatkan volcanoes is communicated using a four-color code similar to that developed by AVO for Alaskan volcanoes. When eruptive ac- $160^{\circ} \mathrm{E}$

Active volcano Seismically monitored volcano (year of last eruption)
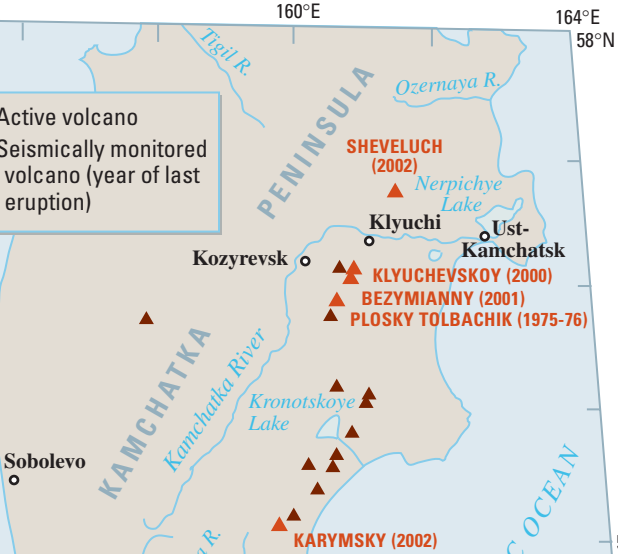

$54^{\circ} \mathrm{N}$
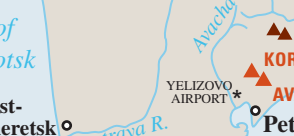

KORYAK
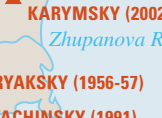

AVACHINSKY (1991)

etsk 0

Petropavlovsk-Kamchatsky

$\Delta \quad \Delta_{\text {MUTNOVSKY }}$

GORELY (1986)
$\triangle_{\text {MUTNOVSKY (1960-61) }}$

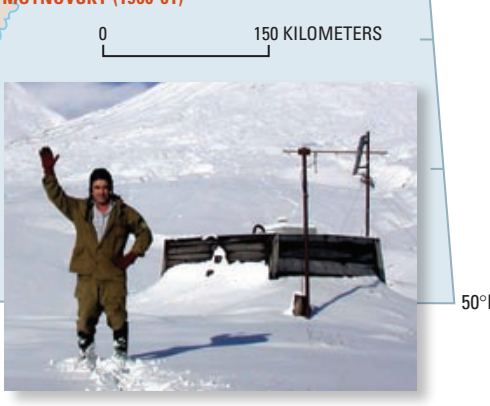

tivity is observed, KVERT uses an emergency call-down procedure to notify the Airport Meteorological Center (AMC) at Yelizovo Airport in Petropavlovsk-Kamchatsky, the Kamchatka Department of Civil Emergency, AVO, and local media and officials. The Yelizovo Airport AMC is responsible for then notifying the Tokyo Volcanic Ash Advisory Center, which in turn issues Volcanic Ash Advisory Statements to the aviation community.

A written description of each eruption is also sent from KVERT to AVO, which then distributes it to more than 200 users by phone, fax, and the Internet. If KVERT reports an eruption with potential impacts to U.S. airspace, AVO directly notifies the National Weather Service, the Federal Aviation Administration, and other U.S. agencies.

A volcano crisis that demonstrated KVERT's value was the 1994 eruption of Klyuchevskoy Volcano in northern Kamchatka. On October 1st, after 3 weeks of low-level eruptive activity tracked and reported by KVERT, an explosive eruption blasted an ash column to a height of more than $49,000 \mathrm{ft}(15 \mathrm{~km})$. Winds of $150 \mathrm{mph}$ $(240 \mathrm{~km} / \mathrm{h})$ blew the ash cloud southeastward more than $620 \mathrm{mi}(1,000 \mathrm{~km})$ over the Pacific Ocean at altitudes of 31,000 to $38,000 \mathrm{ft}(9,500$ to $11,500 \mathrm{~m}$ ), sweeping it across vital air routes in both Russian and U.S. airspace. Within 2 hours of the climactic eruption and of a subse- quent series of ash explosions, KVERT and AVO had notified aviation authorities and air carriers. These warnings, along with guidance from the National Oceanic and Atmospheric Administration (NOAA) on expected movement of ash clouds, enabled dispatchers and air-traffic controllers to safely reroute North Pacific air traffic until the threat subsided.

Since KVERT issued its first information release on the status of Kamchatkan volcanoes, in March 1993, more than 500 information releases and dozens of eruption notifications have been distributed to passenger and cargo airlines, emergency management agencies in the U.S. and Russia, the media, and scientists around the world. KVERT's prompt and reliable reporting has helped ensure that aircraft can safely and efficiently avoid dangerous ash clouds.

In coming decades, air traffic in the North Pacific is projected to increase steadily. The risk of costly, damaging, and possibly deadly encounters of aircraft with volcanic ash clouds will rise accordingly, underscoring the importance of KVERT operations to the safety of air travel in this volcanically active region. To meet this challenge, KVERT and its partners, including USGS, are working to expand monitoring and warning capacity by adding more seismic networks and video systems and by enhancing satellite analysis for Kamchatka and the adjacent Kurile Islands.

Vladimir Yu. Kirianov, Christina A. Neal, Evgenii I. Gordeev, and Thomas P. Miller Edited by

James W. Hendley II and Peter Stauffer Graphic design by

Susan Mayfield and Sara Boore Banner design by Bobbie Myers

COOPERATING ORGANIZATIONS Airline Pilots Association

Alaska Division of Geological and Geophysical Surveys Federal Aviation Administration

Geophysical Institute University of Alaska Fairbanks Institute of Volcanic Geology and Geochemistry, Russian Academy of Sciences International Air Transport Association International Civil Aviation Organization

Kamchatkan Experimental and Methodical Seismological Department, Geophysical Service, Russian Academy of Sciences

National Oceanic and Atmospheric Administration/National

Environmental Satellite Data and Information Service/ Satellite Services Division

National Weather Service/Anchorage Volcanic Ash Advisory Center State Unitary Enterprise Kamchatkaeronavigatziya Tokyo Volcanic Ash Advisory Center, Japan Meteorological Agency U.S. Agency for International Development Yelizovo Airport Meteorological Center

For more information contact:

Alaska Volcano Observatory (907) 786-7497 4200 University Drive Anchorage, AK 99508

http://www.avo.alaska.edu or

http://www.kcs.iks.ru/ivgig

http://data.emsd.iks.ru/video/video.htm http://emsd.iks.ru/ ssl/ http://volcanoes.usgs.gov/

See also Volcanic Ash-Danger to Aircraft in the North Pacific (USGS Fact Sheet 030-97) and Volcanic Ash Fall-A "Hard Rain" of Abrasive Particles (USGS Fact Sheet 027-00) 